\title{
Canadian consensus on medically acceptable wait times for digestive health care
}

\author{
William G Paterson MD FRCPC ${ }^{1}$, William T Depew MD FRCPC ${ }^{1}$, Pierre Paré MD FRCPC ${ }^{2}$, \\ Denis Petrunia MD FRCPC MSc ${ }^{3}$, Connie Switzer MD FRCPC ${ }^{4}$, \\ Sander J Veldhuyzen van Zanten MD FRCPC $\mathrm{PhD}^{5}$, Sandra Daniels $\mathrm{MSc}^{6}$, \\ for the Canadian Association of Gastroenterology Wait Time Consensus Group*
}

WG Paterson, WT Depew, P Paré, et al; for the Canadian Association of Gastroenterology Wait Time Consensus Group. Canadian consensus on medically acceptable wait times for digestive health care. Can J Gastroenterol 2006;20(6):411-423.

BACKGROUND: Delays in access to health care in Canada have been reported, but standardized systems to manage and monitor wait lists and wait times, and benchmarks for appropriate wait times, are lacking. The objective of the present consensus was to develop evidence- and expertise-based recommendations for medically appropriate maximal wait times for consultation and procedures by a digestive disease specialist.

METHODS: A steering committee drafted statements defining maximal wait times for specialist consultation and procedures based on the most common reasons for referral of adult patients to a digestive disease specialist. Statements were circulated in advance to a multidisciplinary group of 25 participants for comments and voting. At the consensus meeting, relevant data and the results of voting were presented and discussed; these formed the basis of the final wording and voting of statements.

RESULTS: Twenty-four statements were produced regarding maximal medically appropriate wait times for specialist consultation and procedures based on presenting signs and symptoms of referred patients. Statements covered the areas of gastrointestinal bleeding; cancer confirmation and screening and surveillance of colon cancer and colonic polyps; liver, biliary and pancreatic disorders; dysphagia and dyspepsia; abdominal pain and bowel dysfunction; and suspected inflammatory bowel disease. Maximal wait times could be stratified into four possible acuity categories of $24 \mathrm{~h}$, two weeks, two months and six months.

FUTURE DIRECTIONS: Comparison of these benchmarks with actual wait times will identify limitations in access to digestive heath care in Canada. These recommendations should be considered targets for future health care improvements and are not clinical practice guidelines.

Key Words: Access; Benchmarks; Consensus; Health care; Wait list; Wait time

\section{Un consensus canadien sur les temps d'attente médicalement acceptables en santé digestive}

HISTORIQUE : Des retards d'accès aux soins de santé sont déclarés au Canada, mais il n'existe ni système universel pour gérer et surveiller les listes et les temps d'attente, ni points de référence pour déterminer des temps d'attente convenables. Le présent consensus visait à élaborer des recommandations probantes fondées sur des compétences pour établir les temps d'attente maximaux médicalement acceptables en vue des consultations et des interventions par des spécialistes de la santé digestive. MÉTHODOLOGIE : Un comité directeur a rédigé des projets de documents définissant les temps d'attente maximaux en vue de consultations et d'interventions avec un spécialiste, d'après les principales raisons d'aiguiller des patients adultes vers un spécialiste de la santé digestive. Ces documents ont été distribués avant une réunion à un groupe multidisciplinaire de 25 participants afin d'obtenir des commentaires et de passer au vote. Pendant la réunion consensuelle, les données pertinentes et les résultats du vote ont été présentés et débattus. Elles ont formé le fondement du texte définitif et du vote à l'égard des documents.

RÉSULTATS : Vingt-quatre documents seront produits sur les temps d'attente maximaux médicalement acceptables en vue de consultations et d'interventions par des spécialistes, d'après les signes et symptômes des patients aiguillés. Les documents portaient sur les saignements gastrointestinaux, la confirmation du cancer et la confirmation et la surveillance du cancer du côlon et des polypes coliques, les troubles hépatiques, biliaires et pancréatiques, la dysphagie et la dyspepsie, les douleurs abdominales et la dysfonction intestinale, de même que la présomption de maladie inflammatoire de l'intestin. Les temps d'attente maximaux pourraient être stratifiés en quatre catégories d'acuité possibles, de 24 heures, deux semaines, deux mois et six mois.

FUTURES ORIENTATIONS : La comparaison de ces points de référence avec les temps d'attente réels permettra de repérer les limites d'accès aux soins de santé digestive au Canada. Ces recommandations devraient être considérées comme des cibles d'améliorations futures des soins de santé et ne constituent pas des directives de pratique clinique.

${ }^{1}$ Queen's University, Hotel Dieu Hospital, Kingston, Ontario; ${ }^{2}$ Université Laval, Hôpital du St-Sacrement, Québec City, Québec;

${ }^{3}$ Victoria General Hospital, Victoria, British Columbia; ${ }^{4}$ University of Alberta, Grey Nuns Community Hospital, Edmonton, Alberta;

${ }^{5}$ Dalhousie University, Queen Elizabeth II Health Sciences Centre, Halifax, Nova Scotia; ${ }^{6}$ Canadian Association of Gastroenterology,

Oakville, Ontario

* See list of voting participants in Appendix

Correspondence: Dr William G Paterson, Queen's University, 166 Brock Street, Kingston, Ontario K7L 5 G2.

Telephone 613-544-3400 ext 3376, fax 613-544-3114, e-mail patersow@hdh.kari.net

Reprints: Canadian Association of Gastroenterology National Office, 2902 South Sheridan Way, Oakville, Ontario L6J 7L6.

Telephone 1-888-780-0007, fax 905-829-0242, e-mail cagoffice@cag-acg.org

Received for publication April 11, 2006. Accepted April 27, 2006 
A ccess to health care services in Canada has come to the fore in recent years. Surveys have shown public dissatisfaction with wait times for care, and media accounts of excessive delays experienced by patients seeking medical attention have been highlighted $(1,2)$. Reports from the profession also point to problems of access. The 2005 Fraser Institute survey of 12 medical specialties found that the median wait time in Canada for specialist consultation was 8.3 weeks, which was considered excessive (3). In response to concerns from patients, the public, health care providers and governments, the federal government recently presented a 10-year plan (4) to strengthen health care. The proposal calls for the establishment, across jurisdictions, of comparable indicators of access to health care professionals, diagnostic and treatment procedures and the development of evidence-based benchmarks for medically acceptable wait times. Provinces and territories are expected to report annually to their citizens on progress in these areas.

The Canadian gastroenterology and hepatology community has long been concerned with access to digestive health care services, including delays for initial specialist consultation, and endoscopic and other diagnostic services. While formal data have not been collected, anecdotal reports suggest that patients wait in excess of one year for nonurgent endoscopy in some parts of the country, which is related to both a shortage of human resources and limited access to facilities for diagnostic services. These delays are even more concerning given the prevalence of digestive problems. In Canada, digestive disease carries the greatest economic burden of all disorders, including that of cancer and cardiovascular disease (5). In addition, benchmarks for what constitute medically appropriate wait times for digestive disease specialist consultation and procedures have not been defined. Accordingly, the Canadian Association of Gastroenterology (CAG) identified human resource planning as a priority and developed a three-pronged approach to elucidate and address problems of access to digestive health care in Canada. Initiatives involve a detailed human resources analysis, including a census of who is providing digestive health care in Canada, the expected number of upcoming retirements and the current number of physicians in gastroenterology training; a nationwide practice audit to quantify wait times for consultation and endoscopic services based on specific diagnoses; and a consensus conference to establish target maximal wait times for digestive health care services based on reason for referral. The present paper reports on the last of the three initiatives.

\section{METHODS}

\section{Membership of the Consensus Group}

A steering committee of community and academic gastroenterologists from across Canada organized and facilitated the consensus process. Multidisciplinary representation was sought by inviting key stakeholder organizations to nominate participants, including the BC Society of Gastroenterology, Alberta Society of Gastroenterology, Ontario Association of Gastroenterology, Association des Gastro-Entérologues du Québec, Atlantic Association of Gastroenterology, Canadian Association for the Study of the Liver, Canadian Association of General Surgeons, Canadian Society of Internal Medicine, The College of Family Physicians of Canada, Quebec chapter of The College of Family Physicians and Canadian Society of Gastroenterology Nurses and Associates (nonvoting participant). Gastroenterologists from
Saskatchewan and Manitoba, along with a pediatric gastroenterologist, took part, and CAG committees of Clinical Affairs, Practice Affairs and Education were represented. The patient perspective on maximal wait times was also sought via a survey completed at selected sites across the country; this will be reported separately. Health and medical organizations invited to send observers included federal and provincial/territorial Ministers of Health, Canadian Institutes of Health Research, Royal College of Physicians and Surgeons of Canada, Federation of National Specialty Societies of Canada, Fraser Institute and the pharmaceutical and medical instrument industries.

\section{Background preparation}

A comprehensive list of the most common reasons for referral of adult patients to a gastroenterologist or hepatologist was developed using referral databases from the Queen Elizabeth II Health Sciences Centre in Halifax, Nova Scotia, and the Hotel Dieu Hospital in Kingston, Ontario. Draft statements outlining maximal target wait times for gastroenterological consultation and procedures were prepared by the steering committee based on the above list, and supporting data from literature searches performed by SvZ, PubMed, EMBASE and the Cochrane databases were explored and guidelines were sought from gastroenterology (American Gastroenterological Association, American College of Gastroenterology, Canadian Association of Gastroenterology) and government (National Institute of Clinical Evidence in the UK and Scottish Intercollegiate Guidelines Network in Scotland) organizations. Four Canadian reports (1-4) that dealt with wait times were also searched for relevant references. Search terms used included 'wait times', 'consultations', 'gastroenterology', 'quality of care', 'review', 'systematic review' and 'specific diagnoses' (eg, dyspepsia, alarm symptoms) or 'reason for referral' (eg, colon cancer screening). The number of citations was generally high, but in most instances, the citations did not deal with the diagnostic yield of consultations or wait times. For all topics, when one or more key citations were found, searches were expanded using the 'related articles' link in MEDLINE. Using this approach, virtually no directly relevant literature on the relationship of clinical outcomes to timeliness of care was identified. Accordingly, the search was expanded to identify literature on the likelihood of serious disease given the presenting signs or symptoms, the impact of the digestive symptom or disorder on patient quality of life and the impact of specialist intervention on outcome. Relevant clinical practice guidelines were also reviewed. Using this approach, 27 statements outlining maximal wait times were drafted by the steering committee and were grouped into the broad categories of gastrointestinal (GI) blood loss; cancer confirmation, screening and diagnosis; liver, biliary and pancreatic disorders; dysphagia and dyspepsia; abdominal pain and bowel dysfunction; and suspected inflammatory bowel disease (IBD). Each steering committee member was responsible for summarizing data in support of statements in one of these six areas and for presenting this to the Consensus Group.

\section{Consensus process and meeting}

Using a modified Delphi approach (6), the 27 draft statements were circulated one month beforehand to consensus participants for prevoting according to the classification system of the Canadian Task Force on Preventative Health Care (formerly known as the Canadian Task Force on the Periodic Health Examination) (7): Accept Completely (a), Accept with Some Reservation (b), Accept with Major Reservation (c), Reject with 
Reservation (d), Reject Completely (e) or Abstain (f). Participants were asked to provide comments for any vote of rejecting or accepting with major reservation (8). Ratings for quality of evidence were not provided for statements because all were considered to be Level III - opinions of respected authorities based on clinical experience, descriptive studies or reports of expert committees (7) - given the lack of data on clinical outcomes related to wait times. Responses from all 25 voting participants were received and summarized in advance of the meeting. A 1.5-day consensus conference was held under the auspices of CAG, in accordance with generally accepted standards for development of clinical practice guidelines (8). Background presentations were given on the topics of wait time initiatives in other specialties, medicolegal aspects of setting wait time benchmarks (The Canadian Medical Protective Association) and patient perspectives on appropriate wait times for digestive health care. Pertinent data were reviewed by a member of the steering committee and were followed by presentation of the original statements and associated preconference voting and comments. One of the two conference co-chairs then elicited discussion and facilitated resolution of the final wording of statements. The statement was accepted if more than $50 \%$ of voting participants chose (a), (b) or (c). At the conclusion of the conference, participants reviewed the list of proposed final statements to ensure consistency. The steering committee drafted the manuscript, which was then circulated for review and comment to voting conference participants. All participants approved the final draft.

\section{STATEMENTS}

Three of the initial 27 statements were found to overlap, and thus, statements were condensed into 24 recommendations. For each statement, a final vote was given and was followed by a brief summary of supporting evidence and key discussion points. All statements relate to patients who were initially assessed by another physician before being referred to the specialist. Timeframes listed are the maximal time between referral and specialist assessment - individual cases may dictate that patients be seen sooner. Wait times relate primarily to the time interval between referral and specialist consultation, but may also apply to subsequent procedures, the timing of which is ultimately at the discretion of the specialist (based on the individual case and clinical judgment). A summary of all recommendations is presented in Table 1 .

\section{GI BLEEDING}

Statement 1: Patients referred with acute GI bleeding should be seen, and if indicated, endoscoped within $24 \mathrm{~h}$ - vote: (a) $100 \%$

Acute upper GI bleeding: Mortality from acute upper GI bleeding has remained unchanged at $5 \%$ to $10 \%$ over several decades, probably due to its occurrence in older patients with comorbid conditions and due to underused endoscopic therapy (9).

Peptic ulcer accounts for more than $50 \%$ of nonvariceal upper GI bleeding cases (10). Risk stratification, based on endoscopic findings, identifies patients at high risk of rebleeding and mortality (11). Endoscopic therapy in patients with high-risk lesions (active bleeding, visible vessel) has been shown to decrease rebleeding, surgery and mortality (12). A retrospective analysis in 909 patients with acute upper GI bleeding showed that early endoscopy (performed within $24 \mathrm{~h}$ versus after $24 \mathrm{~h}$ ) yields better outcomes in high-risk patients (OR 0.21, $\mathrm{P}<0.0001$ for rebleeding and surgery) (13).

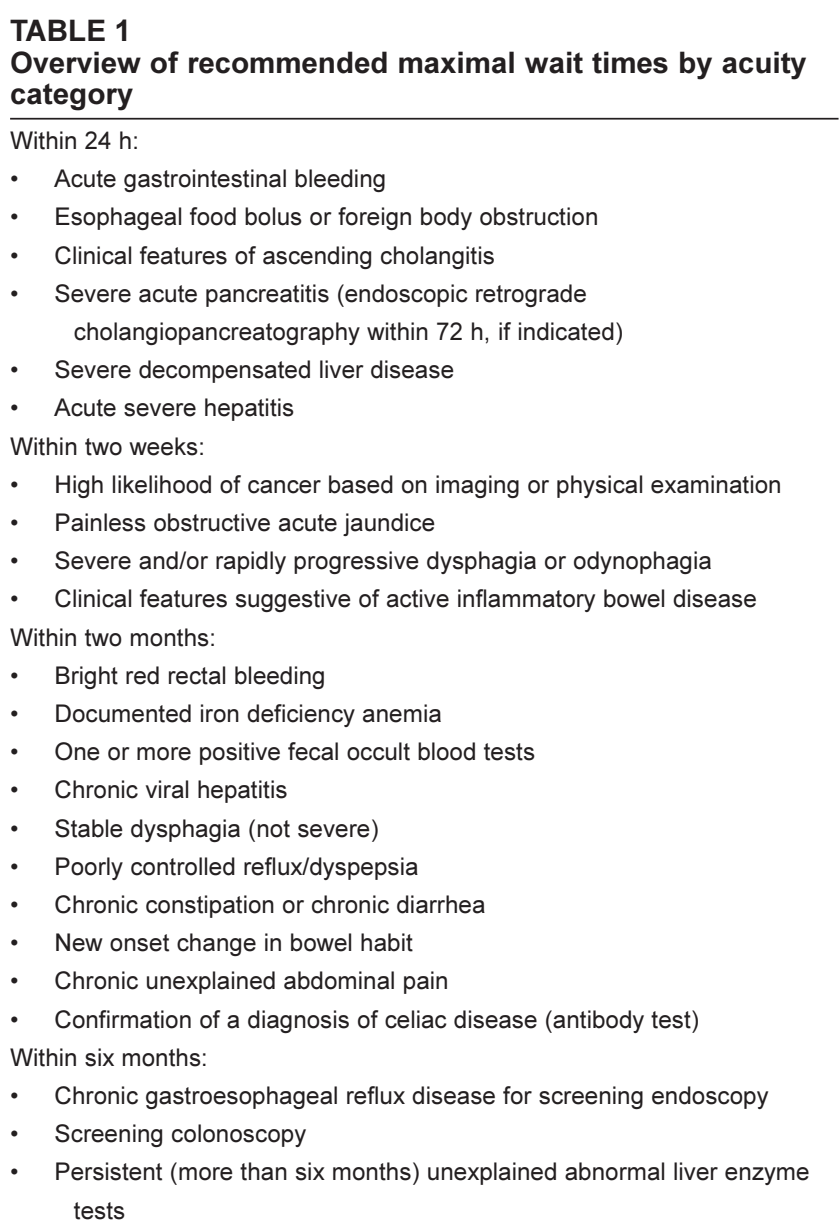

Endoscopic therapy was performed within $24 \mathrm{~h}$ in $76 \%$ of 601 patients with high-risk lesions in the Canadian registry of upper GI bleeding, resulting in decreased rebleeding and/or surgery (OR 0.39) and mortality (OR 0.31) (10). This statement is consistent with the current Canadian consensus guidelines $(9,14)$ on nonvariceal upper GI bleeding, where early stratification into low- and high-risk patients based on clinical and endoscopic criteria, and early endoscopy, are recommended.

In patients with variceal bleeding, early mortality is $5 \%$ to $10 \%$ and increases to $20 \%$ at six weeks. Effective therapy to control bleeding (90\% success rate) and prevent rebleeding (72\% at five days) is available through combined pharmacological and endoscopic therapy $(15,16)$.

In patients with acute upper GI bleeding who are older than 60 years of age, active bleeding or hemodynamic instability at presentation and comorbid conditions (hepatic disease, cardiac failure) are clinical predictors of increased risk for rebleeding and mortality (9) and can therefore be used as key elements to triage and identify those patients at greatest risk.

Acute lower GI bleeding: Overall, acute lower GI bleeding is associated with a mortality rate of less than $5 \%(17,18)$, and in most patients, the bleeding stops spontaneously. Nevertheless, in some patients, severe ongoing or recurrent bleeding requires emergency specialist intervention. 
In two studies $(19,20)$ involving 692 consecutive patients undergoing colonoscopy for suspected lower GI bleeding, diverticulosis was found to be the cause in $17 \%$ to $40 \%$, vascular ectasia in $2 \%$ to $30 \%$, colitis in $9 \%$ to $21 \%$, colonic neoplasia or postpolypectomy bleeding in $11 \%$ to $14 \%$, anorectal source in $4 \%$ to $10 \%$ and an upper GI tract lesion in $0 \%$ to $11 \%$. In three series (21-23) where urgent colonoscopy was performed for acute lower GI bleeding, a specific diagnosis was established in $89 \%$ of 396 patients and endoscopic therapy performed in 9\%. Clinical features (significant versus trivial bleed and greater versus younger than 60 years of age) were shown to be clinical predictors of higher risk of rebleeding (17). However, there is no evidence that endoscopic diagnosis identifies high-risk patients and there are no data available on urgent colonoscopy and its timing related to clinical outcomes. A retrospective analysis suggested that urgent colonoscopy may be cost-saving mostly in intensive care unit and hospital length of stay days (19).

Statement 2: Patients referred with bright red rectal bleeding should be seen, and if indicated, endoscoped within two months - vote: (a) 79\%, (b) 13\%, (c) 4\%, (f) $4 \%$ Epidemiological surveys (24-27) report the prevalence of bright red rectal bleeding to be $15 \%$ to $19 \%$ in individuals older than 20 years, $18 \%$ to $19 \%$ in those younger than 40 years and $8.8 \%$ in those aged 55 to 64 years. Despite this high prevalence, the proportion of individuals seeking health care is low, but increases with age (24). In a series of nine studies (28-36) involving 3221 patients aged 40 to 45 years or older, colonic investigation yielded a prevalence rate of $5 \%$ for colorectal cancer (CRC), 10\% for polyps and 7\% for colitis. In 931 patients younger than 40 years of age, CRC was found in $1 \%$, polyps in $4 \%$ and colitis in $14 \%(31,32,34-37)$. In a sigmoidoscopic screening program in 8507 average-risk patients between 55 and 64 years of age, the risk of CRC was fivefold higher in patients with isolated bleeding without altered bowel habit and 10-fold higher in patients with altered bowel habit (27).

History taking by family physicians or GI specialists is often reported to be a weak predictor of the source of bleeding (anal versus colonic). Some studies $(32,33,38)$ have suggested clinical predictors of CRC: associated change in bowel habits (OR 10), age (OR 8), blood mixed with the stool (OR 8) and bleeding duration of less than two months (OR 3). The Consensus Group recommended the use of these four features to identify patients who require specialist consultation more urgently. One participant accepted the final statement with major reservation on the basis that the OR for the presence of cancer does not support a wait time as short as two months.

Statement 3: Patients referred with documented iron deficiency anemia should be seen, and if indicated, endoscoped within two months - vote: (a) $80 \%$, (b) $20 \%$ In 1019 patients with iron deficiency anemia and a mean age of 60 years or older, the results of bidirectional endoscopy with or without small bowel biopsy were reviewed (39-48). Overall, an upper GI lesion was found in $45 \%$ (37\% to $57 \%$ ) of patients, a colonic lesion in $22 \%$ (16\% to $27 \%)$ and no lesion in $33 \%(14 \%$ to $43 \%)$. Significant or serious lesions included CRC in $10 \%$ of patients, colonic polyps of at least $1 \mathrm{~cm}$ in diameter in $10 \%$, an upper GI tract cancer in $4 \%$ and celiac disease in $4 \%$. In a prospective evaluation of 98 patients, Capurso et al (40) identified predictors of diagnostic outcome - GI cancer, bleeding lesions, lower GI lesions - by multiple logistic regression analysis: significant risk factors were male sex (OR 7.5), advanced age (OR 1.1/year), lower hemoglobin (OR 1.4/unit), lower mean corpuscular volume (OR 1.1/unit), positive fecal occult blood test (OR 4.1) and absence of symptoms (OR 7.6). In 186 premenopausal women presenting with iron deficiency anemia, CRC and gastric cancer were each found in $3 \%$ of patients (49).

\section{Statement 4: Patients referred with one or more positive} fecal occult blood tests should be seen, and if indicated, endoscoped within two months - vote: (a) $64 \%$, (b) $24 \%$, (c) $4 \%$, (f) $8 \%$

Of 823 patients with one or more positive fecal occult blood tests, colonoscopy diagnosed CRC in $4 \%$ to $9 \%$ of patients, colonic polyps greater than $1 \mathrm{~cm}$ in $6 \%$ to $7 \%$ and no lesion in $18 \%$ to $36 \%(50,51)$. After a negative colonoscopy in patients with a mean age greater than 63 years, an upper GI tract cancer was rarely found (zero of 117 patients and one of 365 patients) $(52,53)$. In two prospective studies $(54,55)$ using upper and lower endoscopy in patients at a mean age of greater than 60 years, $\mathrm{CRC}$ was found in $5 \%$ to $8 \%$ of patients, polyps greater than $1 \mathrm{~cm}$ in $12 \%$ and an upper GI tract cancer in $2 \%$; no lesion was found in $50 \%$ of patients. Results of four randomized clinical trials in CRC population screening programs showed a positive predictive value for a positive fecal occult blood test at initial screening of $2.2 \%$ to $17.2 \%$ for CRC and $17 \%$ to $46 \%$ for early carcinoma or large adenoma (56).

One participant who accepted the statement with major reservation believed that a six-month timeframe was more appropriate.

\section{CANCER CONFIRMATION, SCREENING AND SURVEILLANCE}

Statement 5: Patients referred because of a high likelihood of cancer based on imaging or physical examination should be seen, and if indicated, endoscoped within two weeks vote: (a) $100 \%$

Carcinoma suspected on the basis of clinical or radiological investigations requires histological confirmation. Therapy for malignant neoplasms is determined by the cell type and extent (stage) of the cancer at the time of diagnosis. The prognosis for some cancers, including carcinoma of the colon, is related to the stage of the tumour, with early diagnosis implying identification of the tumour at an earlier stage.

The group recognized that although there is no evidence to indicate that adverse outcomes are associated with a delay of several weeks in cancer diagnosis and initiation of therapy, the stress and anxiety of the patient with suspected cancer would mandate urgent assessment within two weeks wherever possible.

Statement 6: Patients with chronic gastroesophageal reflux disease (GERD) referred for screening upper endoscopy should be seen, and if indicated, endoscoped within six months - vote: (a) $4 \%$, (b) $24 \%$, (c) $36 \%$, (d) $36 \%$

The reported increased risk of adenocarcinoma of the esophagus in patients with chronic GERD (57-61), as well as the documented risk of development of adenocarcinoma in Barrett's epithelium (approximately 0.5\%/year) (62-67), are responsible for referrals for endoscopy in patients with chronic GERD. However, endoscopic screening for Barrett's esophagus has not been shown to reduce mortality and has 
important implications for health care delivery given the cost and limited availability of endoscopy (68). The role of a once-in-a-lifetime endoscopy in patients with GERD is perhaps better justified, although the cost-effectiveness remains unproven.

There was considerable discussion of this recommendation given the paucity of evidence to justify cost-effectiveness of screening patients with GERD in a setting of limited resources. However, the majority felt it was reasonable to accept referrals for endoscopic screening in patients with chronic reflux symptoms.

\section{Statement 7: Patients referred for screening colonoscopy} should be seen, and if indicated, endoscoped within six months - vote: (a) 60\%, (b) $40 \%$

$\mathrm{CRC}$ is the third most prevalent cancer affecting Canadian men and women, and one-third of those afflicted will die of the disease. Many of these cancers are preventable by detection and removal of precancerous polyps, and detection of tumours at an early stage may improve prognosis. The CAG and the Canadian Digestive Health Foundation strongly support the establishment of screening programs for CRC and have jointly published national guidelines (69) on stratification of risk for colon cancer, and screening options and recommendations for average- and high-risk groups. Decreased mortality from CRC has been demonstrated in several trials (70-72) using periodic flexible sigmoidoscopy as the screening tool, and it is likely that colonoscopy-based programs are more effective. There are no data to justify the proposed six-month maximum wait time, although results of a questionnaire administered to parents of children awaiting elective procedures indicate that parents believe wait time should never exceed six months (73). The patient questionnaire on acceptable maximal wait times completed in concert with the present consensus also identified patients' reluctance to wait more than six months for low-risk assessments and elective procedures. In addition, scheduling inefficiency and the need for rebooking of appointments may increase with the duration of the wait time $(74,75)$.

\section{LIVER, BILIARY AND PANCREATIC DISORDER STATEMENTS}

Statement 8: Patients referred with clinical features of ascending cholangitis should be seen, and if indicated, have endoscopic retrograde cholangiopancreatography (ERCP) performed within $24 \mathrm{~h}$ - vote: (a) $100 \%$

The risks of morbidity and mortality escalate rapidly in patients with extrahepatic biliary obstruction complicated by biliary sepsis, particularly in those patients with hypotension, pyrexia greater than $39^{\circ} \mathrm{C}$ or with altered mental state (76). Mortality in the most severely ill may reach $50 \%$ even with prompt treatment (77). Many such patients suffer from significant comorbid disorders that substantially enhance these risks. Ascending cholangitis is a medical emergency requiring aggressive antibiotic administration, fluid resuscitation and biliary decompression. Although as many as $80 \%$ of cases will stabilize temporarily with antibiotics alone, up to $20 \%$ will deteriorate rapidly within the first $24 \mathrm{~h}$ despite antibiotic treatment. These patients must be rescued with emergency biliary decompression (78-80). Accordingly, it was recommended unanimously that patients referred with ascending cholangitis be assessed and, if indicated, treated by ERCP and biliary decompression within $24 \mathrm{~h}$.
Statement 9: Patients referred with acute severe pancreatitis should be seen within $24 \mathrm{~h}$, and if indicated, have ERCP performed within $72 \mathrm{~h}$ - vote: (a) $100 \%$

Severe acute pancreatitis (Ranson's score 4 or more points [81], Glasgow score 3 or more points [82], Apache II with body mass index [83], hematocrit greater than 44\% [84]) is a medical emergency. Mortality rates can exceed $80 \%$ in the most extreme cases (85) and clinical deterioration may occur rapidly within $24 \mathrm{~h}$. Meticulous medical management, including vigorous fluid resuscitation, respiratory support, timely nutritional support and vigilance for pancreatic sepsis, is the primary component of successful treatment (86). Choledocholithiasis accounts for a substantial fraction of patients with severe acute pancreatitis. Clinical studies provide clear evidence of reductions in morbidity and mortality from early ERCP with stone extraction/biliary decompression in selected cases of severe pancreatitis of gallstone origin (87-89). Standard of care for patients with severe acute pancreatitis, regardless of the etiology, demands specialty care, usually in an intensive care environment, in a facility with appropriate imaging capability (computed tomography scanning) and general surgical support. Thus, it was recommended unanimously that patients referred with severe acute pancreatitis be assessed within $24 \mathrm{~h}$ and treated, if indicated, by ERCP with stone extraction/biliary decompression within $72 \mathrm{~h}$.

Statement 10: Patients referred with severe decompensated liver disease should be seen within $24 \mathrm{~h}$ - vote: (a) 100\% Chronic liver diseases may decompensate following a host of complications such as GI bleeding (from varices), infection (as in spontaneous bacterial peritonitis), ascites, hepatorenal syndrome, hepatocellular carcinoma and hepatic encephalopathy. Alternatively, end-stage decompensation may present as rapidly progressive deterioration in liver function tests (bilirubin, prothrombin time and albumin) in the absence of an obvious precipitant. Without specialty care, mortality associated with these events is high. In each instance, early medical evaluation and, if indicated, aggressive medical treatment, is essential to provide time for any chance of hepatic recovery/stabilization. Therefore, it was recommended that patients referred with decompensated chronic liver diseases should be assessed within $24 \mathrm{~h}$ of the recognition of the event(s).

Statement 11: Patients referred with severe acute hepatitis should be assessed within $24 \mathrm{~h}$ - vote: (a) 60\%, (b) $40 \%$

Acute liver failure (ALF) - international normalized ratio greater than 1.5 and altered mental state in a patient without pre-existing cirrhosis and with an illness of less than 26 weeks in duration - and death may follow acute liver injury due to viral (eg, hepatitis A virus, hepatitis B virus/hepatitis delta virus, hepatitis $\mathrm{C}$ virus, hepatitis $\mathrm{E}$ virus, Epstein-Barr virus, herpes simplex) or autoimmune hepatitis, drug-induced (eg, acetaminophen and alcohol) liver injury, metabolic (eg, Wilson's disease and fatty liver of pregnancy) liver injury and shock/ischemia (90). Mortality rates in such cases may be as high as $80 \%$, depending on the etiology of the hepatic insult and the degree of hepatic decompensation (90). The progress of ALF may be very fast, with significant life-threatening deterioration occurring within $24 \mathrm{~h}$ in some cases (91). Patients with severe liver injury without ALF features usually recover, but it is from this subset that the potential cases of ALF derive. 
The development of ALF identifies the subgroup at immediate high risk for mortality. Many such patients will require referral to a transplant centre as part of the medical management. Standard of care should include early meticulous medical treatment and observation by specialists, usually in an intensive care environment, and timely referral to a transplant facility (91).

There are no universal criteria enabling a completely reliable diagnosis of the ALF precursor in severe liver injury, but most experts agree that severe liver injury is characterized by relatively high and progressively rising serum bilirubin levels (greater than $250 \mu \mathrm{mol} / \mathrm{L}$ ), progressively increasing prothrombin times (international normalized ratio of 1.5), progressively decreasing albumin levels (less than $30 \mathrm{~g} / \mathrm{L}$ ), associated renal insufficiency and the appearance of ascites (91). Of even greater concern among those with lesser degrees of severe liver injury are patients with idiosyncratic drug injury, patients over 40-years-old and those pregnant, particularly in the third trimester (91). Accordingly, it was recommended that patients referred with severe acute liver injury be assessed by a specialist (eg, gastroenterologist or hepatologist) within $24 \mathrm{~h}$.

Statement 12: Patients referred with painless, obstructive acute jaundice should be seen within two weeks - vote:

(a) $84 \%$, (b) $12 \%$, (c) $4 \%$

While the majority of patients presenting with new-onset painless jaundice have extrahepatic biliary obstruction, some will have an intrahepatic cause such as cholestatic drug toxicity. For patients with ancillary imaging evidence (ultrasound, computed tomography scanning, magnetic resonance imaging) supporting a diagnosis of obstruction, relief of the obstruction is necessary to minimize hepatic injury, truncate the related nutritional compromise, eliminate cholestatic pruritus and avoid biliary sepsis. The duration of obstruction in these patients usually substantially exceeds the duration of symptoms. Although emergent biliary decompression in the absence of sepsis is rarely indicated, it was concluded that, in the presence of evidence supporting a mechanical cause, patients referred with painless jaundice should be assessed within two weeks so that appropriate biliary decompression can be executed in a timely fashion.

Statement 13: Patients referred with chronic viral hepatitis should be seen within two months - vote: (a) $46 \%$, (b) $50 \%$, (d) $4 \%$

The chronic viral hepatitides (hepatitis B and hepatitis C) are usually slowly progressive necroinflammatory diseases that culminate in fibrosis and cirrhosis over a period of several years $(92,93)$. Standard of care of typical uncomplicated cases demands methodical medical evaluation and an individualized decision for treatment by specialists $(94,95)$. Management of patients with hepatitis $\mathrm{B} / \mathrm{HIV}$ or hepatitis C/HIV coinfection is more complex and the coinfected patient may experience more rapidly progressive disease. Furthermore, although in the majority of patients a prolonged delay in initiating treatment is unlikely to adversely affect outcome, it is recognized that patient anxiety about these well publicized diseases is high. Therefore, a maximal wait time of two months was endorsed. One participant who voted to reject this recommendation with reservation did so on the basis that a maximal wait time of six months was more appropriate.
Statement 14: Patients referred because of persistent (more than six months) unexplained abnormal liver enzyme tests should be seen within six months - vote: (a) $42 \%$, (b) $50 \%$, (c) $8 \%$

Isolated abnormalities of the commonly available liver enzyme tests (aspartate aminotransferase, alanine aminotransferase, alkaline phosphatase) account for a substantial fraction of consultations to specialists (96). For patients referred with such isolated increases (up to five times the upper limit of normal), in the absence of clinical symptoms of hepatobiliary disease, urgent assessment is rarely, if ever, medically necessary. In many cases, the abnormalities are transient and clinically insignificant. For asymptomatic patients with sustained increases for longer than six months in whom preliminary investigations, including viral serologies and a careful druginduced liver injury review, have not identified a possible etiology, consultation evaluation is appropriate $(96,97)$. The majority of such cases will have nonalcoholic fatty liver disease, a condition which is often benign or at the worst, has a very slow progression (over many years). Other chronic hepatic disorders such as primary biliary cirrhosis, hemochromatosis (ferritin increased, transferrin saturation greater than $50 \%$ ), sclerosing cholangitis and autoimmune hepatitis may also present in this way, but even these conditions do not normally require urgent specialist assessment for appropriate medical management in asymptomatic patients with no clinical examination abnormalities.

It was recognized that the identification of even mild liver test abnormalities is stressful in a significant number of patients and that long delays to specialist consultation may create considerable anxiety. It was also recognized that in certain circumstances, more urgent evaluation might be crucial for other reasons. For example, many patients with such mild test abnormalities are discovered during routine screening for insurance purposes. The timing of a specialist consultation could influence the outcome of such seemingly unrelated matters. Accordingly, it was recommended that patients referred for evaluation of unexplained, sustained (greater than six months) asymptomatic increases of the common liver enzyme tests (up to five times the upper limit of normal) should normally be assessed within six months.

\section{DYSPHAGIA AND DYSPEPSIA}

Statement 15: Patients referred with esophageal food bolus or foreign body obstruction should be seen and endoscoped within $24 \mathrm{~h}$ - vote: (a) $92 \%$, (b) $4 \%$, (f) $4 \%$

No citations were found that specifically evaluated the timeframe within which patients should be seen for esophageal food bolus or foreign body obstruction. However, there is agreement that patients should be promptly evaluated and treated within $24 \mathrm{~h}$. Recent data suggest that the complication rate from bolus or foreign body obstruction, including aspiration and esophageal perforation, increases if endoscopy is postponed beyond $24 \mathrm{~h}$ (98).

\section{Statement 16: Patients referred with dysphagia and/or} odynophagia that is severe or rapidly progressing should be seen, and if indicated, endoscoped within two weeks vote: (a) $96 \%$, (b) $4 \%$

Dysphagia refers to difficulty in swallowing and should be distinguished from odynophagia, a painful sensation as the food bolus traverses the esophagus. The group noted that 
symptom severity may dictate appropriate wait time. Troublesome dysphagia, especially for solids, which is progressive, is an indication for a prompt evaluation that should generally occur within two weeks, because serious underlying disease is more likely. Sudden onset of severe odynophagia can be the result of acute infectious esophagitis or pill-induced injury and requires prompt diagnosis and therapy because of symptom severity and because therapy is based on the endoscopic findings.

Dysphagia, especially when progressive over time, is considered an alarm symptom. Recent studies have indeed confirmed that this symptom is associated with an increased risk of detecting upper GI cancer. In a recent United Kingdom study (99) evaluating a clinical prediction model for upper GI cancer, the overall prevalence of cancer in two consecutive cohorts of 1852 and 1785 patients was 3.8\%. The risk of detecting a cancer was increased if dysphagia was present (OR 3.1) as was weight loss (OR 2.6) and age greater than 55 years (OR 9.5). A recent meta-analysis (100) evaluated the diagnostic value of alarm symptoms of upper GI malignancy in 17 case-control studies and nine cohort studies. The mean prevalence of GI malignancy in the selected studies was $2.8 \%$. The predictive value of individual alarm symptoms including dysphagia varied from $4.6 \%$ to $7.9 \%$, and this value was $5.9 \%$ for the presence of any alarm symptom. Absence of alarm symptoms made the presence of cancer less likely; the pooled negative predictive value was $99.4 \%$ (99).

Statement 17: Patients referred with stable dysphagia that is not severe should be seen, and if indicated, endoscoped within two months - vote: (a) $92 \%$, (b) $8 \%$

Dysphagia is a general term encompassing symptoms of varying severity and presentation. Minor dysphagia is common in patients with GERD, being reported by $38 \%$ of patients in one large study (101), and generally responding rapidly to proton pump inhibitor therapy. Although consensus was high for this statement, participants who accepted with some reservation did so on the basis that patients need not be assessed and endoscoped if symptoms completely resolve with proton pump inhibitor therapy.

Statement 18: Patients referred with poorly controlled reflux symptoms or other dyspepsia symptoms but no alarm symptoms should be seen, and if indicated, endoscoped within two months - vote: (a) $54 \%$, (b) $46 \%$

There was a high degree of consensus that these patients should be evaluated and, if necessary, endoscoped. Although such an approach is endorsed by various guidelines $(68,102)$, there is very little evidence from controlled clinical trials to support the usefulness and cost-effectiveness of performing upper GI endoscopy in patients with dyspepsia and reflux symptoms (103-106). Nevertheless, there is evidence that health care costs may be lower and patient satisfaction greater for patients undergoing gastroscopy than for patients receiving empiric therapy for dyspepsia (107-109). This may, in part, be explained by the reassurance of a negative endoscopy. Furthermore, for patients with long-standing reflux symptoms, there is concern about Barrett's esophagus and the associated risk of development of esophageal adenocarcinoma (see Statement 6).

Statement 19: Patients referred with dyspepsia and associated alarm symptoms (eg, vomiting, weight loss, GI blood loss) should be seen, and if indicated, endoscoped within two months - vote: (a) $8 \%$, (b) $88 \%$, (c) $4 \%$

Most physicians are cognizant of upper GI alarm symptoms and features such as vomiting, evidence of bleeding, presence of an abdominal mass, unintentional weight loss and dysphagia, and refer such patients for investigation (110). While this makes clinical sense, literature regarding alarm symptoms as predictors of serious underlying disease is minimal. Low positive and high negative predictive values for presence and absence of alarm symptoms, respectively, were found in the evaluation of 2479 consultations for dyspepsia in primary care in Denmark (111). This is explained by the low prevalence of cancer $(4 \%)$ in patients with alarm symptoms in the study.

Given the lack of strong evidence to support the use of alarm symptoms as indicators of serious disease, a two-month timeframe for evaluation was agreed on. However, those who accepted the statement with some or major (one participant) reservation did so because they thought a two-month wait in the presence of alarm symptoms to be too long.

\section{ABDOMINAL PAIN AND BOWEL DYSFUNCTION}

Statement 20*: Patients referred with unexplained chronic diarrhea or chronic constipation should be seen, and if indicated, colonoscoped within two months - vote: (a) 4\%, (b) $75 \%$, (c) $21 \%$

Statement $21 *$ : Patients referred with new-onset change in bowel habit should be seen, and if indicated, colonoscoped within two months - vote: (a) $12.5 \%$, (b) $87.5 \%$

Statement 22*: Patients referred with chronic unexplained abdominal pain should be seen within two months vote: (a) 33\%, (b) 63\%, (c) 4\%

* Statements 20 through 22 relate to the first assessment by the specialist and not to repeat consultation requests. Because the rationale underlying these statements is similar, they are grouped together.

Studies reporting the diagnostic yield in patients with lower GI symptoms are relatively scant, but they do suggest that the likelihood of serious underlying disease in these patients is very low. In a large series of nearly 4000 colonoscopies (112), colon cancer was found in $4.4 \%$ of patients referred with abdominal pain, $5.8 \%$ in those referred with a change in bowel habit and $6.8 \%$ in those referred with abdominal pain and change in bowel habit. This compares with $9.1 \%$ in those referred with overt rectal bleeding.

With public health education campaigns on colon cancer stressing that symptoms such as change in bowel habit, diarrhea, constipation and change in stool calibre may be related to cancer, many patients are understandably concerned when these symptoms arise, making prolonged wait times for consultation stressful.

Quality of life is markedly impaired in people with diarrhea $(113,114)$ and constipation (115). In addition, untreated diarrhea has significant economic consequences. In the United States, it is estimated that diarrhea accounts for more than three million days of missed work per year at an estimated cost of US $\$ 350$ million (116). Thus, timely access to a specialist for assessment and treatment of diarrhea is desirable. There are also a number of studies showing impaired quality of life in 
irritable bowel syndrome (IBS) patients. Indeed, scores on the Short-Form 36 questionnaire in IBS patients are comparable with those of patients with chronic congestive heart failure or diabetes (117). Loss of work days is also an important problem in IBS patients, who have almost double the average absenteeism as a control population (118). Furthermore, in one study (119), it was reported that more than $50 \%$ of IBS patients avoid work, travel, socializing, sex, domestic and leisure activities and specific food intake.

Thus, patients presenting with one or more of these lower GI symptoms, although unlikely to have serious underlying organic disease, have significant health impairment with consequent personal and economic costs. In addition, a number of studies suggest that specialist intervention in functional GI disorders such as IBS will improve symptoms and decrease health utilization (120-122). Taken together, this evidence supports the recommendation that a wait of no more than two months is appropriate for patients with chronic abdominal pain, diarrhea, constipation or a symptom complex suggestive of IBS. The consensus participants who had significant reservations about the above statements did so on the basis that serious disease was very unlikely to accompany most of these symptoms, therefore a longer wait time was reasonable. It was also suggested that a shorter wait time would be appropriate if the patient was older than 50 years of age.

\section{SUSPECTED IBD}

Statement 23: Patients referred with clinical features highly suggestive of significant active IBD should be seen, and if indicated, endoscoped within two weeks - vote: (a) $58 \%$, (b) $42 \%$

At least one million Americans have IBD and 30,000 new cases are diagnosed every year (123). Based on Manitoba data, the incidence and prevalence may actually be higher in Canada (124). IBD also carries a large economic burden to both society and the patient, with total costs (direct and indirect) exceeding $\$ 1.25$ billion per year in the United States (123). In Canada, it is estimated that work absenteeism due to IBD costs the country more than $\$ 100$ million annually (125).

Delay in diagnosis is common in Crohn's disease. In one large study (126), 10\% of patients with small bowel Crohn's disease took more than 10 years to diagnose and only $21 \%$ were correctly diagnosed on initial investigation of symptoms. Assessing the effects of delay in the diagnosis of IBD is difficult because the diseases are complex and differ in severity by patient. Pediatric studies clearly demonstrate that IBD has a negative impact on growth velocity, weight gain, bone mineral density and pubertal development (127), with some of these effects reversed with early intervention and treatment. In adults, the negative impact of IBD on the quality of life has been found to improve with disease control (128).

Evidence that early diagnosis changes the outcomes of adult Crohn's disease is indirect. Better outcomes were observed in pediatric Crohn's patients with use of 6-mercaptopurine and prednisone with high remission rates $(89 \%)$ and low relapse rates (9\% at 1.5 years compared with $47 \%$ in the control group), suggesting that early and effective treatment is linked to better outcomes (129). In addition, pediatric Crohn's patients with disease of less than two years in duration have a longer response to a single dose of infliximab compared with those with longer disease duration (130). Adults who responded to infliximab had fewer hospitalizations and less surgery, again suggesting that effective therapy improves outcomes by reducing complications (131).

Early diagnosis and intervention may improve outcomes, but more research is needed to answer these questions directly. "Studies are beginning to suggest that 'early institution' of an 'aggressive approach' offers the possibility to avoid complications such as stenosis, fistula formation and growth retardation" (132).

Statement 24: Patients referred for confirmation of a diagnosis of celiac disease (antibody testing positive) should be seen, and if indicated, endoscoped within two months vote: (a) $79 \%$, (b) $17 \%$, (c) $4 \%$

The prevalence of celiac disease is much higher than previously thought, with serological screening demonstrating the prevalence at $0.5 \%$ to $1.0 \%$ in the general population (133). The availability of serological screening tests for celiac disease has heightened the awareness of this disorder and placed new pressures on the gastroenterologist for consultation and diagnosis. Long delays in the diagnosis of celiac disease (mean of 11 years), even in symptomatic patients, have been reported (134). Since the introduction of screening serology tests, only $47 \%$ of newly diagnosed celiac patients present with diarrhea, while $57 \%$ present with atypical symptoms or as the result of screening asymptomatic patients with a family history of celiac disease. To complicate matters, many patients are being given a glutenfree diet based on positive serology before biopsy, which may prevent accurate diagnosis. On this basis alone, early duodenal biopsy is appropriate to ensure an accurate and timely diagnosis.

The evidence that early diagnosis and treatment in celiac disease improves outcomes is evolving. The mortality rate in patients with celiac disease is 1.9 to 3.8 times higher than in the general population (135-137), largely because of malignant disease. Recent studies suggest that increased mortality is reversed in compliant patients following a strict gluten-free diet (138). The delay in diagnosing celiac disease leads to complications related to nutrient malabsorption, such as anemia and osteoporosis $(139,140)$. The most compelling evidence comes from a birth cohort of 5470 children in the United Kingdom followed over 7.5 years. Asymptomatic children with positive celiac serology were significantly shorter and weighed less $(\mathrm{P}<0.001)$ compared with normal children with negative serology (141).

The other important factor is the reliability of serology. The National Institutes of Health (NIH) Consensus Development Conference on Celiac Disease states that "all diagnostic tests need to be performed while the patient is on a gluten-containing diet" (142). The NIH literature review demonstrated equal performance of antitissue transglutaminase antibody and antiendomysial antibody tests in adults. The NIH states "small bowel biopsies are indicated in any individual with a positive celiac disease antibody test" and that "for individuals who have been placed on a gluten-free diet without an appropriate diagnostic evaluation, testing should follow a gluten challenge".

Reasons to expedite endoscopy and biopsy for celiac patients are to ensure that an accurate diagnosis is made before starting a gluten-free diet, to reduce the long delay in diagnosis, to reduce the negative consequences of prolonged celiac disease, to institute and encourage compliance with a gluten-free diet, to improve the patient's quality of life and to hopefully reduce the risks of malignancy. 
The participants who accepted with some or major (one participant) reservation expressed concern that the statement should reflect that a gluten-free diet should not be started until after the diagnosis is established on biopsy.

\section{DISCUSSION}

In recent years, improving access to health care services in Canada has been an increasing focus of patients and the public, governments, health care providers and the media. In a 2002-2003 survey (1), the top unmet health care need reported by $32 \%$ of Canadians was 'waiting too long for care'. In a second large survey (2) on access to health care services, approximately one in five individuals who saw a specialist for a new illness or condition experienced difficulties in access to care, with long waits identified as the primary barrier. Among those who waited for specialist care, $29 \%$ reported unacceptable wait times and one in five who waited for a diagnostic test deemed the wait to be unacceptable. Data from health care providers also point to increasing wait times. The Fraser Institute's annual waiting list survey (3) of 12 medical specialties indicated that the median wait time between referral from a general practitioner and specialist consultation has remained high at 8.3 to 8.4 weeks since 2003; similarly, the wait between referral and treatment remained at 17.7 to 17.9 weeks over this period.

But how long is too long? A 1998 report (143) commissioned by Health Canada highlighted the paucity of wait time information and identified an urgent need for national investment in the creation of standardized and well-monitored systems for wait time assessment and management. The report also noted the need to develop clinical benchmarks for appropriate wait times as a means of evaluating existing services and improving access to health care. A 2004 discussion paper (144) authored by the Canadian Medical Association and the Canadian Nurses Association echoed Health Canada's findings, calling for the establishment of wait time benchmarks that incorporate clinical criteria and public preferences.

In response to increasing concerns, the first ministers in February 2003 announced an agenda for health care renewal, and in September 2004 they presented a 10-year plan to strengthen health care (4). The plan called for each jurisdiction to establish comparable indicators of access to health care professionals and evidence-based benchmarks for medically acceptable wait times, starting with cancer, heart disease, diagnostic imaging procedures, joint replacement and sight restoration. As a result, wait time initiatives are under way in several disease areas $(145,146)$.

The CAG has developed a comprehensive, three-pronged approach to exploring access to digestive health care in Canada. The first initiative involves quantifying current and anticipated demands for digestive disease specialists for adult patients based on information extracted from databanks such as the Canadian Institute of Health Information's National Physician Database. In the second initiative, the Practice Audit in Gastroenterology (PAGE) program, specialists from across the country have documented wait times for adult patients for gastroenterological and hepatology consultation or diagnostic services. The present consensus represents the third facet of the strategy, namely, development of wait time benchmarks for digestive disease specialist consultation and associated diagnostic services.

A consensus approach to create evidence-based recommendations for medically appropriate wait times has been advocated
$(143,144)$ and was used in the present consensus. However, studies directly evaluating medical outcomes as a function of wait time for gastroenterological care are lacking. Hence, data on the risk for serious underlying disease based on presenting symptoms and signs were used to support wait time recommendations. In addition, the effect of the symptom on patient quality of life, and the beneficial effect of physician intervention in improving symptoms, decreasing health utilization and allaying patient fears of serious disease were also considered by the Consensus Group. Lastly, public perspective, in the form of a survey on wait times administered to patients by the consensus steering committee, was taken into account in these recommendations and will be reported separately.

Most data available on wait lists in Canada deal with patients who have already been assessed, such as those waiting for bypass or cataract surgery or for specialized diagnostic testing, such as magnetic resonance imaging. This CAG initiative is unique in that it deals predominantly with wait times of patients who have symptoms or signs that remain undiagnosed after assessment by a primary care physician. In addition, we included patients with emergency conditions (eg, acute GI bleeding, ascending cholangitis) who would not be placed on a waiting list per se. However, by setting benchmarks for specialist access in these emergency conditions, we hope to set standards for timely transfer of critically ill patients from remote locations or community hospitals to the appropriate secondary or tertiary care centre.

It is important that these recommendations be understood in the proper context. The wait times proposed here are maximal; some patients may need to be assessed sooner. To keep recommendations simple, acuity categories of $24 \mathrm{~h}$, two weeks, two months and six months were used, and the group avoided creating many specific statements to address every eventuality. Instead, where applicable, clinical predictors that may warrant more urgent attention were identified. A particular symptom may have a number of different underlying causes, and detailed information supplied by referring physicians including test findings can assist specialists in their assessment. Lastly, these benchmarks relate only to adults with digestive disorders; a similar undertaking in pediatrics would be required to define target wait times in this population.

Finally, it is vital that physicians, regional health organizations, and governments recognize that these benchmarks are not practice guidelines, but a health care goal for which to strive. Indeed, preliminary analysis (147) of the PAGE IV data indicates that because of current resource limitations, many of these wait time targets are not being met. Attempts to immediately implement targets in isolation without careful consideration of the many issues and individuals involved in health care delivery is likely to prove ineffective and may indeed worsen the problem.

\section{APPENDIX: LIST OF ATTENDEES}

\section{Steering committee}

William Paterson (WP) - Chair, Pierre Paré (PP), Denis Petrunia (DP),

Connie Switzer (CS), Sander Veldhuyzen van Zanten (SV).

\section{Conference moderators}

William Depew (WD), Jonathan Meddings (JM). The moderator was permitted to vote on sessions he was not responsible for chairing. 


\section{APPENDIX: LIST OF ATTENDEES - CONTINUED}

\section{Other voting participants}

Alan Barkun (AB), Ronald Bridges (RB), Sonny Dhalla (SD), Nigel Flook (NF), Michael Gould (MG), James Gray (JG), Ziad Hassoun (ZH), Desmond Leddin (DL), Peter Lightfoot (PL), William Mackie (WM), Peggy Marcon (PMa), Paul Moayyedi (PMo), J de la Rey Nel (JN), Sandra Nelles (SN), Daniel Sadowski (DS), Thomas Sylwestrowicz (TS), Laura Targownik (LT), Anthony Tavenor (AT), Malcolm Wilson (MW).

\section{Nonvoting participant}

Lorie McGeough (LM)

\section{Represented societies and committees}

Alberta Society of Gastroenterology (DS), Atlantic Association of Gastroenterology (PL), BC Society of Gastroenterology (JG), Canadian Association of Gastroenterology (CAG) (DL), CAG Clinical Affairs Committee $(A B), C A G$ Education Committee (RB), CAG Practice Affairs Committee (DS), Canadian Association of General Surgeons (WM), Canadian Society of Gastroenterology Nurses and Associates (LM), Canadian Society of Internal Medicine (MW), College of Family Physicians of Canada (NF), Ontario Association of Gastroenterology (MG), Association des Gastro-Entérologues du Québec (PP)

\section{Nonvoting observers}

Hassen Abdullah, Therapeutic Products Directorate, Health Canada; Michel Brazeau, Chief Executive Officer, Royal College of Physicians and Surgeons of Canada; Brenda Ryan, Information Products Development, Nova Scotia Department of Health; representatives of the pharmaceutical and medical instrument industries; and the CAG National Office.

ACKNOWLEDGEMENTS: CAG thanks the sponsors, AstraZeneca Canada Inc, Axcan Pharma Inc, Hoffmann-La Roche Ltd, Janssen-Ortho Inc, Abbott Laboratories Ltd, Altana Pharma Inc and Schering Canada Inc for their unrestricted educational grant in support of the meeting.

CONFLICT OF INTEREST: No, I do not have any industrial or government relationships to report (ZH, WM, PMa, LM, JN, SN, CS, TS, AT, MW).

RECEIPT OF CONSULTATION FEES: Abbott (RB, NF, PP), Altana (AB, RB, PP, DP), AstraZeneca (AB, SD, NF, MG, JM, PMo, PP, DP, SV), Axcan (RB, DP), EbMed (SV), Ferring (RB), JanssenOrtho (AB, RB, NF, DP), Johnson \& Johnson (NF), Merck (NF), Novartis (RB, NF, PP, WP, SV), Pfizer (NF), Procter \& Gamble (PP), Sanofi (NF), Solvay (SD, PP), Tyco (SD), Wyeth (NF).

RECEIPT OF RESEARCH GRANTS: Altana (AB, LT), AstraZeneca (AB, DS, SV), Canadian Institutes of Health Research (WD, WP), Crohn's \& Colitis Foundation of Canada (DL), Eli Lilly (DL, DS), Human Resources Development Canada (DL), Janssen-Ortho (AB), Mayo Clinic Rochester (DL), Novartis (DS), Veterans Administration, US (WD).

RECEIPT OF CLINICAL TRIAL FUNDING: Abbott (PP, DP, DS, SV), Altana (AB, DL, PP), AstraZeneca (AB, JG, PP, DP, SV), Axcan (PP, SV), Berlex (PP), Centocor (PP), Elan (PP), GlaxoSmithKline (DL, PP), Hoffmann-La Roche (WD), ICON (PP), Janssen-Ortho (AB, JG), Millennium (PP), Novartis (JG, PP, WP, SV), Otsuka (WD, PP), Pfizer (SV), Robarts Research Institute (WD), Schering (WD), Solvay (DS), Tillotts (PP), VSL (PP), Wyeth (PP).

PARTICIPATION IN SPEAKER'S BUREAU: Abbott (RB, NF, PP), Altana (AB, RB, PP), AstraZeneca (AB, SD, NF, PP),
Axcan (RB), Janssen-Ortho (AB, RB, NF, PP), Johnson \& Johnson (NF), Merck (NF), Novartis (RB, NF, PP), Pfizer (NF), Schering (PP), Solvay (SD, PP), Tyco (SD), Wyeth (NF).

OTHER: Altana (PL), AstraZeneca (PL, PMo), Axcan (PL), CIHR Committee work (AB), Eli Lilly (PL), Ferring (PL), Hoffmann-La Roche (PL), Schering (PL). This Consensus Conference was endorsed and organized by the Canadian Association of Gastroenterology and was held in Toronto, Ontario, on January 15-16, 2005.

\section{REFERENCES}

1. Statistics Canada. Joint Canada/United States Survey of Health. $<$ http://www.statcan.ca/english/freepub/82M0022XIE/ 82M0022XIE2003001.htm> (Version current at May 9, 2006).

2. Statistics Canada. Access to Health Care Services in Canada, 2003. $<$ http://www.statcan.ca/english/freepub/82-575-XIE/2003001/ report.htm> (Version current at May 9, 2006).

3. Fraser Institute. Waiting Your Turn: Hospital Waiting Lists in Canada. $<$ http://www.fraserinstitute.ca/shared/readmore.asp?sNav=pb\&id=801> (Version current at May 9, 2006).

4. Health Canada. Health Care System. A 10-year plan to strengthen health care. September 16, 2004. <http://www.hc-sc.gc.ca/hcs-sss/ delivery-prestation/fptcollab/2004-fmm-rpm/nr-cp_9_16_2_e.html> (Version current at May 9, 2006).

5. Beck IT. Disproportion of economic impact, research achievements and research support in digestive diseases in Canada. Clin Invest Med 2001;24:12-36

6. Dalkey N. The Delphi Method: An experimental study of group opinion. Futures 1969;408-26.

7. Goldbloom R, Battista RN. The periodic health examination: 1. Introduction. CMAJ 1986;134:721-3.

8. Lomas J. Words without action? The production, dissemination, and impact of consensus recommendations. Annu Rev Publ Health 1991;12:41-65.

9. Barkun A, Bardou M, Marshall JK; Nonvariceal Upper GI Bleeding Consensus Conference Group. Consensus recommendations for managing patients with nonvariceal upper gastrointestinal bleeding. Ann Int Med 2003;139:843-57.

10. Barkun A, Sabbah S, Enns R, et al; RUGBE Investigators. The Canadian Registry on Nonvariceal Upper Gastrointestinal Bleeding and Endoscopy (RUGBE): Endoscopic hemostasis and proton pump inhibition are associated with improved outcomes in a real-life setting. Am J Gastroenterol 2004;99:1238-46.

11. Laine L, Peterson WL. Bleeding peptic ulcer. N Engl J Med 1994:331:717-27.

12. Cook DJ, Guyatt GH, Salena BJ, Laine LA. Endoscopic therapy for acute nonvariceal upper gastrointestinal hemorrhage: A meta-analysis. Gastroenterology 1992;102:139-48.

13. Cooper GS, Chak A, Way LE, Hammar PJ, Harper DL, Rosenthal GE. Early endoscopy in upper gastrointestinal hemorrhage: Associations with recurrent bleeding, surgery, and length of hospital stay. Gastrointest Endosc 1999;49:145-52.

14. Barkun A, Fallone CA, Chiba N, et al; Nonvariceal Upper GI Bleeding Consensus Conference Group. A Canadian clinical practice algorithm for the management of patients with nonvariceal upper gastrointestinal bleeding. Can J Gastroenterol 2004;18:605-9.

15. Lebrec D, Vinel JP, Dupas JL. Complications of portal hypertension in adults: A French consensus. Eur J Gastroenterol Hepatol 2005; 17:403-10.

16. Banares R, Albillos A, Rincon D, et al. Endoscopic treatment versus endoscopic plus pharmacologic treatment for acute variceal bleeding: A meta-analysis. Hepatology 2002;35:609-15.

17. Bramley PN, Masson JW, McKnight G, et al. The role of an openaccess bleeding unit in the management of colonic haemorrhage. A 2-year prospective study. Scand J Gastroenterol 1996;31:764-9.

18. Longstreth GF. Epidemiology and outcome of patients hospitalized with acute lower gastrointestinal hemorrhage: A population-based study. Am J Gastroenterol 1997;92:419-24.

19. Jensen DM, Machicado GA. Colonoscopy for diagnosis and treatment of severe lower gastrointestinal bleeding. Routine outcomes and cost analysis. Gastrointest Endosc Clin N Am 1997;7:477-98. 
20. Vernava AM III, Moore BA, Longo WE, Johnson FE. Lower gastrointestinal bleeding. Dis Colon Rectum 1997;40:846-58.

21. Kok KY, Kum CK, Goh PM. Colonoscopic evaluation of severe hematochezia in an Oriental population. Endoscopy 1998;30:675-80.

22. Chaudhry V, Hyser MJ, Gracias VH, Gau FC. Colonoscopy: The initial test for acute lower gastrointestinal bleeding. Am Surg 1998;64:723-8

23. Jensen DM, Machicado GA, Jutabha R, Kovacs TO. Urgent colonoscopy for the diagnosis and treatment of severe diverticular hemorrhage. N Engl J Med 2000;342:78-82.

24. Talley NJ, Jones M. Self-reported rectal bleeding in a United States community: Prevalence, risk factors, and health care seeking. Am J Gastroenterol 1998;93:2179-83.

25. Dent OF, Goulston KJ, Zubrzycki J, Chapuis PH. Bowel symptoms in an apparently well population. Dis Colon Rectum 1986;29:243-7.

26. Crosland A, Jones R. Rectal bleeding: Prevalence and consultation behaviour. BMJ 1995;311:486-8

27. Ferraris R, Senore C, Fracchia M, et al; SCORE Working Group. Predictive value of rectal bleeding for distal colonic neoplastic lesions in a screened population. Eur J Cancer 2004;40:245-52.

28. Brand EJ, Sullivan BH Jr, Sivak MV Jr, Rankin GB. Colonoscopy in the diagnosis of unexplained rectal bleeding. Ann Surg 1980;192:111-3.

29. Goulston KJ, Cook I, Dent OF. How important is rectal bleeding in the diagnosis of bowel cancer and polyps? Lancet 1986;2:261-5.

30. Church JM. Analysis of the colonoscopic findings in patients with rectal bleeding according to the pattern of their presenting symptoms. Dis Colon Rectum 1991;34:391-5.

31. Korkis AM, McDougall CJ. Rectal bleeding in patients less than 50 years of age. Dig Dis Sci 1995;40:1520-3.

32. Helfand M, Marton KI, Zimmer-Gembeck MJ, Sox HC Jr. History of visible rectal bleeding in a primary care population. Initial assessment and 10-year follow-up. JAMA 1997;277:44-8

33. Segal WN, Greenberg PD, Rockey DC, Cello JP, McQuaid KR. The outpatient evaluation of hematochezia. Am J Gastroenterol 1998;93:179-82.

34. Fine KD, Nelson AC, Ellington RT, Mossburg A. Comparison of the color of fecal blood with the anatomical location of gastrointestinal bleeding lesions: Potential misdiagnosis using only flexible sigmoidoscopy for bright red blood per rectum. Am J Gastroenterol 1999:94:3202-10

35. Mulcahy HE, Patel RS, Postic G, et al. Yield of colonoscopy in patients with nonacute rectal bleeding: A multicenter database study of 1766 patients. Am J Gastroenterol 2002;97:328-33.

36. Lewis JD, Shih CE, Blecker D. Endoscopy for hematochezia in patients under 50 years of age. Dig Dis Sci 2001;46:2660-5.

37. Acosta JA, Fournier TK, Knutson CO, Ragland JJ. Colonoscopic evaluation of rectal bleeding in young adults. Am Surg 1994;60:903-6.

38. Fijten GH, Starmans R, Muris JW, Schouten HJ, Blijham GH, Knottnerus JA. Predictive value of signs and symptoms for colorectal cancer in patients with rectal bleeding in general practice. Fam Pract 1995;12:279-86.

39. McIntyre AS, Long RG. Prospective survey of investigations in outpatients referred with iron deficiency anaemia. Gut 1993;34:1102-7.

40. Capurso G, Baccini F, Osborn J, et al. Can patient characteristics predict the outcome of endoscopic evaluation of iron deficiency anemia: A multiple logistic regression analysis. Gastrointest Endosc 2004;59:766-71.

41. Rockey DC, Cello JP. Evaluation of the gastrointestinal tract in patients with iron-deficiency anemia. N Engl J Med 1993;329:1691-5.

42. Karnam US, Felder LR, Raskin JB. Prevalence of occult celiac disease in patients with iron-deficiency anemia: A prospective study. South Med J 2004:97:30-4.

43. Bampton PA, Holloway RH. A prospective study of the gastroenterological causes of iron deficiency anaemia in a general hospital. Aust N Z J Med 1996;26:793-9.

44. Gordon SR, Smith RE, Power GC. The role of endoscopy in the evaluation of iron deficiency anemia in patients over the age of 50. Am J Gastroenterol 1994;89:1963-7.

45. Cook IJ, Pavli P, Riley JW, Goulston KJ, Dent OF. Gastrointestinal investigation of iron deficiency anaemia. Br Med J (Clin Res Ed) 1986:292:1380-2

46. Kepczyk T, Kadakia SC. Prospective evaluation of gastrointestinal tract in patients with iron-deficiency anemia. Dig Dis Sci $1995 ; 40: 1283-9$
47. Coban E, Timuragaoglu A, Meric M. Iron deficiency anemia in the elderly: Prevalence and endoscopic evaluation of the gastrointestinal tract in outpatients. Acta Haematol 2003;110:25-8.

48. Hardwick RH, Armstrong CP. Synchronous upper and lower gastrointestinal endocopy is an effective method of investigating iron-deficiency anaemia. Br J Surg 1997;84:1725-8.

49. Bini EJ, Micale PL, Weinshel EH. Evaluation of the gastrointestinal tract in premenopausal women with iron deficiency anemia Am J Med 1998;105:281-6.

50. Eisner MS, Lewis JH. Diagnostic yield of a positive fecal occult blood test found on digital rectal examination. Does the finger count? Arch Intern Med 1991;151:2180-4.

51. Levin B, Hess K, Johnson C. Screening for colorectal cancer. A comparison of 3 fecal occult blood tests. Arch Intern Med 1997;157:970-6.

52. Chen YK, Gladden DR, Kestenbaum DJ, Collen MJ. Is there a role for upper gastrointestinal endoscopy in the evaluation of patients with occult blood-positive stool and negative colonoscopy? Am J Gastroenterol 1993;88:2026-9

53. Bini EJ, Rajapaksa RC, Valdes MT, Weinshel EH. Is upper gastrointestinal endoscopy indicated in asymptomatic patients with a positive fecal occult blood test and negative colonoscopy? Am J Med 1999;106:613-8.

54. Zuckerman G, Benitez J. A prospective study of bidirectional endoscopy (colonoscopy and upper endoscopy) in the evaluation of patients with occult gastrointestinal bleeding. Am J Gastroenterol 1992;87:62-6.

55. Rockey DC, Koch J, Cello JP, Sanders LL, McQuaid K. Relative frequency of upper gastrointestinal and colonic lesions in patients with positive fecal occult-blood tests. N Engl J Med 1998;339:153-9.

56. Lang CA, Ransohoff DF. What can we conclude from the randomized controlled trials of fecal occult blood test screening? Eur J Gastroenterol Hepatol 1998;10:199-204.

57. Lagergren J, Bergstrom R, Lindgren A, Nyren O. Symptomatic gastroesophageal reflux as a risk factor for esophageal adenocarcinoma. N Engl J Med 1999;340:825-31.

58. Velanovich V, Hollingsworth J, Suresh P, Ben-Menachem T. Relationship of gastroesophageal reflux disease with adenocarcinoma of the distal esophagus and cardia. Dig Surg 2002;19:349-53.

59. Green JA, Amaro R, Barkin JS. Symptomatic gastroesophageal reflux as a risk factor for esophageal adenocarcinoma. Dig Dis Sci 2000;45:2367-8.

60. Avidan B, Sonnenberg A, Schnell TG, Chejfec G, Metz A, Sontag SJ Hiatal hernia size, Barrett's length, and severity of acid reflux are all risk factors for esophageal adenocarcinoma. Am J Gastroenterol 2002;97:1930-6.

61. Farrow DC, Vaughan TL, Sweeney C, et al. Gastroesophageal reflux disease, use of $\mathrm{H} 2$ receptor antagonists, and risk of esophageal and gastric cancer. Cancer Causes Control 2000;11:231-8.

62. Spechler SJ, Lee E, Ahnen D, et al. Long-term outcome of medical and surgical therapies for gastroesophageal reflux disease: Follow-up of a randomized controlled trial. JAMA 2001;285:2331-8.

63. Provenzale D, Schmitt C, Wong JB. Barrett's esophagus: A new look at surveillance based on emerging estimates of cancer risk. Am J Gastroenterol 1999;94:2043-53.

64. Rana PS, Johnston DA. Incidence of adenocarcinoma and mortality in patients with Barrett's oesophagus diagnosed between 1976 and 1986: Implications for endoscopic surveillance. Dis Esophagus 2000;13:28-31.

65. O'Connor JB, Falk GW, Richter JE. The incidence of adenocarcinoma and dysplasia in Barrett's esophagus: Report on the Cleveland Clinic Barrett's Esophagus Registry. Am J Gastroenterol 1999;94:2037-42

66. Drewitz DJ, Sampliner RE, Garewal HS. The incidence of adenocarcinoma in Barrett's esophagus: A prospective study of 170 patients followed 4.8 years. Am J Gastroenterol 1997;92:212-5.

67. Conio M, Blanchi S, Lapertosa G, et al. Long-term endoscopic surveillance of patients with Barrett's esophagus. Incidence of dysplasia and adenocarcinoma: a prospective study. Am J Gastroenterol 2003;98:1931-9.

68. Armstrong D, Marshall JK, Chiba N, et al. Canadian Consensus Conference on the management of gastroesophageal reflux disease in adults - Update 2004. Can J Gastroenterol 2005;19:15-35.

69. Leddin D, Hunt R, Champion M, et al; Canadian Association of Gastroenterology; Canadian Digestive Health Foundation. Canadian Association of Gastroenterology and the Canadian Digestive Health 
Foundation: Guidelines on colon cancer screening. Can J Gastroenterol 2004;18:93-9.

70. Mandel JS. Screening of patients at average risk for colon cancer. Med Clin North Am 2005;89:43-59, vii.

71. Selby JV, Friedman GD, Quesenberry CP Jr, Weiss NS. A case-control study of screening sigmoidoscopy and mortality from colorectal cancer. N Engl J Med 1992;326:653-7.

72. Newcomb PA, Norfleet RG, Storer BE, Surawicz TS, Marcus PM. Screening sigmoidoscopy and colorectal cancer mortality. J Natl Cancer Inst 1992;84:1572-5.

73. Miller GG. Waiting for an operation: Parents' perspectives. Can J Surg 2004;47:179-81.

74. Hamilton W, Round A, Sharp D. Patient, hospital, and general practitioner characteristics associated with non-attendance: A cohort study. Br J Gen Pract 2002;52:317-9.

75. Murdock A, Rodgers C, Lindsay H, Tham TC. Why do patients not keep their appointments? Prospective study in a gastroenterology outpatient clinic. J R Soc Med 2002;95:284-6.

76. Boey JH, Way LW. Acute cholangitis. Ann Surg 1980;191:264-70.

77. DenBesten L, Doty, JE. Pathogenesis and management of choledocholithiasis. Surg Clin North Am 1981;61:893-907.

78. Lai EC, Mok FP, Tan ES, et al. Endoscopic biliary drainage for severe acute cholangitis. N Engl J Med 1992;326:1582-6.

79. Leese T, Neoptolemos JP, Baker AR, Carr-Locke DL. Management of acute cholangitis and the impact of endoscopic sphincterotomy. Br J Surg 1986;73:988-92.

80. Lai EC, Tam PC, Paterson IA, et al. Emergency surgery for severe acute cholangitis. The high-risk patients. Ann Surg 1990;211:55-9.

81. Ranson JH, Rifkind KM, Roses DF, Fink SD, Eng K, Spencer FC. Prognostic signs and the role of operative management in acute pancreatitis. Surg Gynecol Obstet 1974;139:69-81.

82. Corfield AP, Cooper MJ, Williamson RC, et al. Prediction of severity in acute pancreatitis: Prospective comparison of three prognostic indices. Lancet 1985;2:403-7.

83. Triester SL, Kowdley KV. Prognostic factors in acute pancreatitis. J Clin Gastroenterol 2002;34:167-76.

84. Brown A, Orav J, Banks PA. Hemoconcentration is an early marker for organ failure and necrotizing pancreatitis. Pancreas 2000;20:367-72.

85. Isenmann R, Rau B, Beger HG. Early severe acute pancreatitis: Characteristics of a new subgroup. Pancreas 2001;22:274-8.

86. Working Party of the British Society of Gastroenterology; Association of Surgeons of Great Britain and Ireland; Pancreatic Society of Great Britain and Ireland; Association of Upper GI Surgeons of Great Britain and Ireland. UK guidelines for the management of acute pancreatitis. Gut 2005;54(Suppl 3):iii1-iii9.

87. Neoptolemos JP, Carr-Locke DL, London NJ, Bailey IA, James D, Fossard DP. Controlled trial of urgent endoscopic retrograde cholangiopancreatography and endoscopic sphincterotomy versus conservative treatment for acute pancreatitis due to gallstones. Lancet 1988;2:979-83.

88. Fan ST, Lai EC, Mok FP, Lo CM, Zheng SS, Wong J. Early treatment of acute biliary pancreatitis by endoscopic papillotomy. N Engl J Med 1993;328:228-32.

89. Barkun AN. Early endoscopic management of acute gallstone pancreatitis - an evidence-based review. J Gastrointest Surg 2001;5:243-50.

90. Ostapowicz G, Fontana RJ, Schiodt FV, et al; US Acute Liver Failure Study Group. Results of a prospective study of acute liver failure at 17 tertiary care centers in the United States. Ann Int Med 2002;137:947-54

91. Polson J, Lee WM; American Association for the Study of Liver Disease. AASLD position paper: The management of acute liver failure. Hepatology 2005;41:1179-97.

92. Thomas DL, Seeff LB. Natural history of hepatitis C. Clin Liver Dis 2005;9:383-98, vi.

93. Tran TT, Martin P. Hepatitis B: Epidemiology and natural history. Clin Liver Dis 2004;8:255-66.

94. Sherman M, Bain V, Villeneuve JP, et al. The management of chronic viral hepatitis: A Canadian consensus conference 2004. Can J Gastroenterol 2004;18:715-28.

95. Liaw YF, Leung N, Guan R, et al. Asian-Pacific consensus statement on the management of chronic hepatitis B: A 2005 update. Liver Int 2005;25:472-89

96. Minuk GY. Canadian Association of Gastroenterology Practice Guidelines: Evaluation of abnormal liver enzyme tests. Can J Gastroenterol 1998;12:417-21.
97. AGA Clinical Practice Committee. American Gastroenterological Association medical position statement: Evaluation of liver chemistry tests. Gastroenterology 2002;123:1364-66.

98. Chaves DM, Ishioka S, Felix VN, Sakai P, Gama-Rodrigues JJ. Removal of a foreign body from the upper gastrointestinal tract with a flexible endoscope: A prospective study. Endoscopy 2004;36:887-92.

99. Kapoor N, Bassi A, Sturgess R, Bodger K. Predictive value of alarm features in a rapid access upper gastrointestinal cancer service. Gut 2005;54:40-5.

100. Fransen GA, Janssen MJ, Muris JW, Laheij RJ, Jansen JB. Metaanalysis: The diagnostic value of alarm symptoms for upper gastrointestinal malignancy. Aliment Pharmacol Ther 2004;20:1045-52.

101. Vakil NB, Traxler B, Levine D. Dysphagia in patients with erosive esophagitis: Prevalence, severity, and response to proton pump inhibitor treatment. Clin Gastroenterol Hepatol 2004:2:665-8.

102. Veldhuyzen van Zanten SJ, Bradette M, Chiba N, et al; Canadian Dyspepsia Working Group. Evidence-based recommendations for short-and long-term management of uninvestigated dyspepsia in primary care: An update of the Canadian Dyspepsia Working Group (CanDys) clinical management tool. Can J Gastroenterol 2005;19:285-303.

103. Ofman JJ, Rabeneck L. The effectiveness of endoscopy in the management of dyspepsia: A qualitative systematic review. Am J Med 1999;106:335-46.

104. Axon AT. Chronic dyspepsia: Who needs endoscopy? Gastroenterology 1997;112:1376-80.

105. Fendrick AM, Chernew ME, Hirth RA, Bloom BS. Alternative management strategies for patients with suspected peptic ulcer disease. Ann Intern Med 1995;123:260-8.

106. Silverstein MD, Petterson T, Talley NJ. Initial endoscopy or empirical therapy with or without testing for Helicobacter pylori for dyspepsia: A decision analysis. Gastroenterology 1996;110:72-83.

107. Bytzer P, Hansen JM, Schaffalitzky de Muckadell OB. Empirical H2-blocker therapy or prompt endoscopy in management of dyspepsia. Lancet 1994;343:811-6.

108. Barkun A, Crott R, Fallone C, et al. The cost effectiveness of alternative strategies in the management of patients with uninvestigated dyspepsia: The Candys approach using ranitidine versus omeprazole as anti-secretory medication. Gastroenterology 2002;122(Suppl 1):465. (Abst)

109. Barkun A, Crott R, Fallone C, et al. The cost-effectiveness of alternative strategies in the short-term management of patients with uninvestigated dyspepsia: The Candys approach versus empiric anti-secretory therapy using omeprazole. Gastroenterology 2002;122(Suppl 1):474. (Abst)

110. Veldhuyzen van Zanten SJ, Flook N, Chiba N, et al. An evidence based approach to the management of uninvestigated dyspepsia in the era of Helicobacter pylori. Canadian Dyspepsia Working Group. CMAJ 2000;162(Suppl 12):S3-23.

111. Meineche-Schmidt V, Jorgensen T. 'Alarm symptoms' in patients with dyspepsia: A three-year prospective study from general practice. Scand J Gastroenterol 2002;37:999-1007.

112. Neugut AI, Garbowski GC, Waye JD, et al. Diagnostic yield of colorectal neoplasia with colonoscopy for abdominal pain, change in bowel habits, and rectal bleeding. Am J Gastroenterol 1993;88:1179-83.

113. Watson A, Samore MH, Wanke CA. Diarrhea and quality of life in ambulatory HIV-infected patients. Dig Dis Sci 1996;41:1794-800.

114. Lubeck DP, Bennett CL, Mazonson PD, Fifer SK, Fries JF. Quality of life and health service use among HIV-infected patients with chronic diarrhea. J Acquir Immune Defic Syndr 1993;6:478-84.

115. Irvine EJ, Ferrazzi S, Pare P, Thompson WG, Rance L. Health-related quality of life in functional GI disorders: Focus on constipation and resource utilization. Am J Gastroenterol 2002;97:1986-93.

116. Brown D, Everhart JE. Cost of digestive diseases in the United States. In: Everhart JE, ed. Digestive diseases in the United States: Epidemiology and impact. US Department of Health and Human Services, National Institutes of Health, National Institutes of Diabetes and Digestive and Kidney Diseases. Washington: US Government Printing Office, 1994:55-82.

117. Groll D, Vanner SJ, Depew WT, et al. The IBS-36: A new quality of life measure for irritable bowel syndrome. Am J Gastroenterol 2002;97:962-71.

118. Drossman DA, Li Z, Andruzzi E, et al. US householder survey of functional gastrointestinal disorders. Prevalence, sociodemography, and health impact. Dig Dis Sci 1993;38:1569-80. 
119. Corney RH, Stanton R. Physical symptom severity, psychological and social dysfunction in a series of outpatients with irritable bowel syndrome. J Psychosom Res 1990;34:483-91.

120. Owens DM, Nelson DK, Talley NJ. The irritable bowel syndrome: Long-term prognosis and the physician-patient interaction. Ann Intern Med 1995;122:107-12.

121. Thompson WG, Heaton KW, Smyth GT, Smyth C. Irritable bowel syndrome in general practice: Prevalence, characteristics, and referral. Gut 2000;46:78-82.

122. Ilnyckyj A, Graff LA, Blanchard JF, Bernstein CN. Therapeutic value of a gastroenterology consultation in irritable bowel syndrome. Aliment Pharmacol Ther 2003;17:871-80.

123. Loftus EV Jr. Clinical epidemiology of inflammatory bowel disease: Incidence, prevalence, and environmental influences. Gastroenterology 2004;126:1504-17.

124. Bernstein CN, Blanchard JF, Rawsthorne P, Wajda A. Epidemiology of Crohn's disease and ulcerative colitis in a central Canadian province: A population-based study. Am J Epidemiol 1999;149:916-24.

125. Longobardi T, Jacobs P, Wu L, Bernstein CN. Work losses related to inflammatory bowel disease in Canada: Results from a National Population Health Survey. Am J Gastroenterol 2003;98:844-9.

126. Admans H, Whorwell PJ, Wright R. Diagnosis of Crohn's disease. Dig Dis Sci 1980;25:911-5.

127. Stephens M, Batres LA, Ng D, Baldassano R. Growth failure in the child with inflammatory bowel disease. Semin Gastrointest Dis 2001; $12: 253-62$.

128. Irvine EJ, Grace E, Kerr GD, et al. Problems which address health related quality of life (HRQOL) in inflammatory bowel disease (IBD). Gastroenterology 1998;114:1002. (Abst)

129. Markowitz J, Grancher K, Kohn N, Lesser M, Daum F. A multicenter trial of 6-mercaptopurine and prednisone in children with newly diagnosed Crohn's disease. Gastroenterology 2000;119:895-902.

130. Kugathasan S, Werlin SL, Martinez A, Rivera MT, Heikenen JB, Binion DG. Prolonged duration of response to infliximab in early but not late pediatric Crohn's disease. Am J Gastroenterol 2000;95:3189-94.

131. Hanauer SB, Feagan BG, Lichtenstein GR, et al; ACCENT I Study Group. Maintenance infliximab for Crohn's disease: The ACCENT I randomised trial. Lancet 2002;359:1541-9.

132. D'Haens G. Mucosal healing in pediatric Crohn's disease: The goal of medical treatment. Inflamm Bowel Dis 2004;10:479-80.

133. Fasano A, Berti I, Gerarduzzi T, et al. Prevalence of celiac disease in at-risk and not-at-risk groups in the United States: A large multicenter study. Arch Intern Med 2003;163:286-92.

134. Green PH, Jabri B. Coeliac disease. Lancet 2003;362:383-91.
135. Logan RF, Rifkind EA, Turner ID, Ferguson A. Mortality in celiac disease. Gastroenterology 1989;97:265-71.

136. Cottone M, Termini A, Oliva L, et al. Mortality and causes of death in celiac disease in a Mediterranean area. Dig Dis Sci $1999 ; 44: 2538-41$

137. Corrao G, Corazza GR, Bagnardi V, et al; Club del Tenue Study Group. Mortality in patients with coeliac disease and their relatives: A cohort study. Lancet 2001;358:356-61.

138. Collin P, Reunala T, Pukkala E, Laippala P, Keyrilainen O, Pasternack A. Coeliac disease - Associated disorders and survival. Gut 1994;35:1215-8.

139. Patterson RN, Johnston SD. Iron deficiency anaemia: Are the British Society of Gastroenterology guidelines being adhered to? Postgrad Med J 2003;79:226-8.

140. Switzer CM, Cranney AB, Graham AD, et al. Canadian celiac health survey. Gastroenterology 2004;126:248. (Abst)

141. Bingley PJ, Williams AJ, Norcross AJ, et al; Avon Longitudinal Study of Parents and Children Study Team. Undiagnosed coeliac disease at age seven: Population based prospective birth cohort study. BMJ 2004;328:322-3.

142. National Institutes of Health. National Institutes of Health Consensus Development Conference Statement on Celiac Disease. <http://consensus.nih.gov/2004/2004CeliacDisease118html.htm> (Version current at May 9, 2006)

143. Health Canada. Waiting Lists and Waiting Times for Health Care in Canada. More Management!! More Money?? Summary Report July 1998. <www.hc-sc.gc.ca/ahc-asc/media/nr-cp/1998/1998_50_e.html> (Version current at April 7, 2006).

144. Canadian Medical Association. The Taming of the queue: Toward a cure for health care wait times. Discussion Paper July 2004. $<$ www.cma.ca/multimedia/staticcontent/CMA/Content_Images/ Inside_cma/Media_Releases/pdf/Taming-Queue.pdf $>$ (Version current at May 9, 2006).

145. Western Canada Waiting List Project. From chaos to order: Making sense of waiting lists in Canada. Final Report May 1, 2001. $<$ www.wcwl.ca/media/pdf/library/final_reports.2.pdf $>$ (Version current at May 9, 2006)

146. Canadian Medical Association. It's About Time! Achieving benchmarks and best practices in wait time management. August 2005. <www.cma.ca/multimedia/CMA/Content_Images/ Inside_cma/Media_Release/pdf/2005/wta-final.pdf $>$ (Version current at May 9, 2006).

147. Leddin D, Hunt R, Armstrong D, et al. Wait times for gastroenterological (GI) consultation and investigation: A novel approach to resource planning in gastroenterology. Can J Gastroenterol 2006;20(Suppl A):58A. (Abst) 


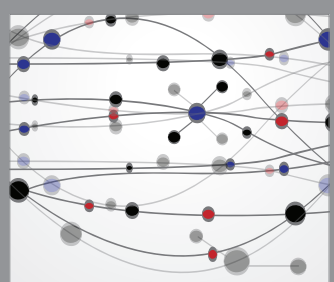

The Scientific World Journal
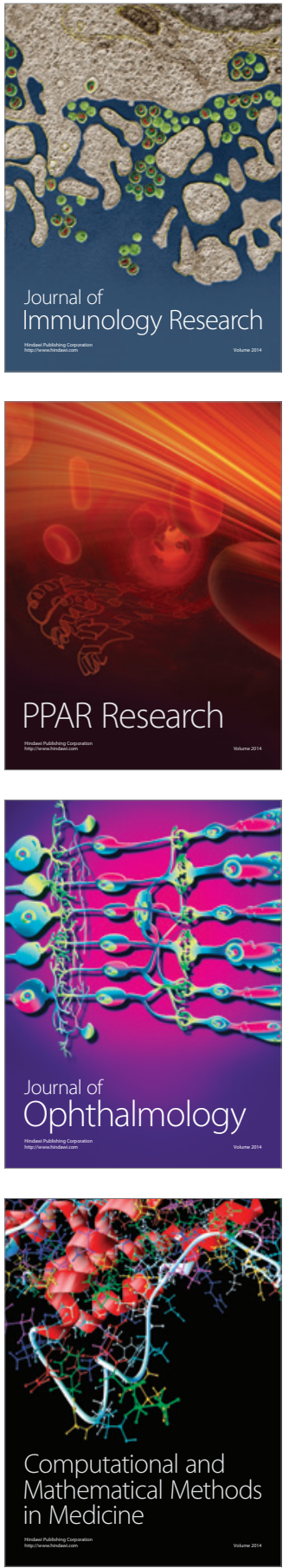

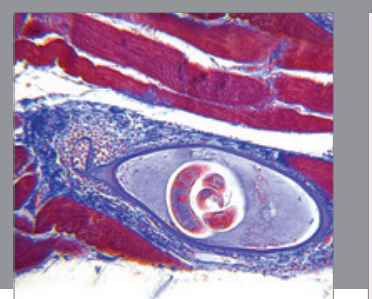

Gastroenterology Research and Practice

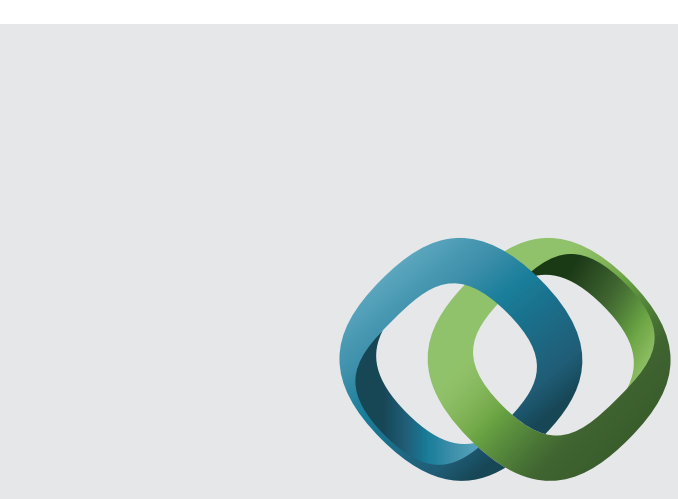

\section{Hindawi}

Submit your manuscripts at

http://www.hindawi.com
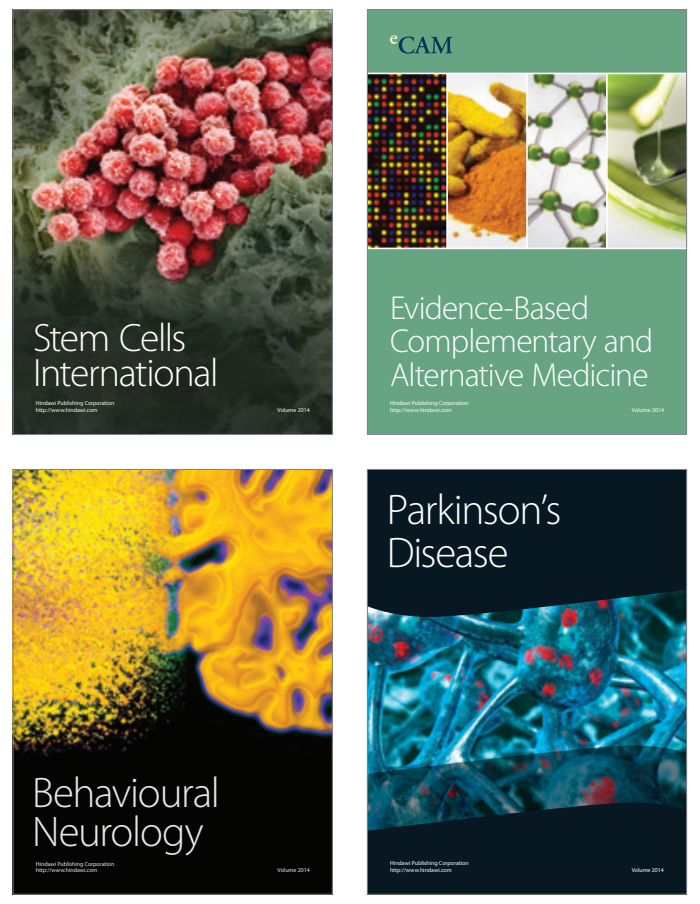
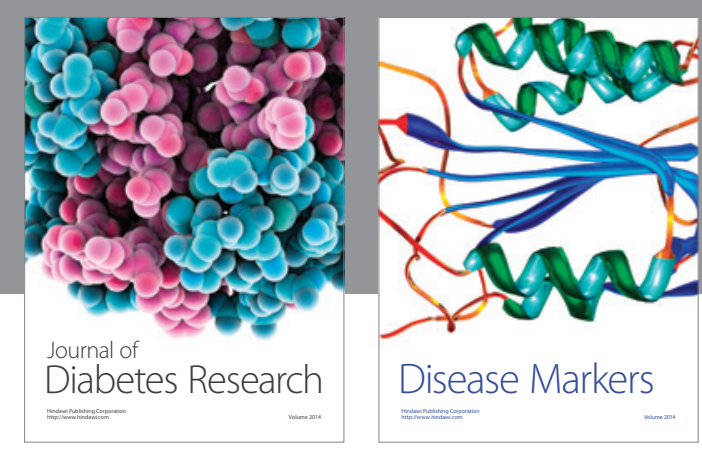

Disease Markers
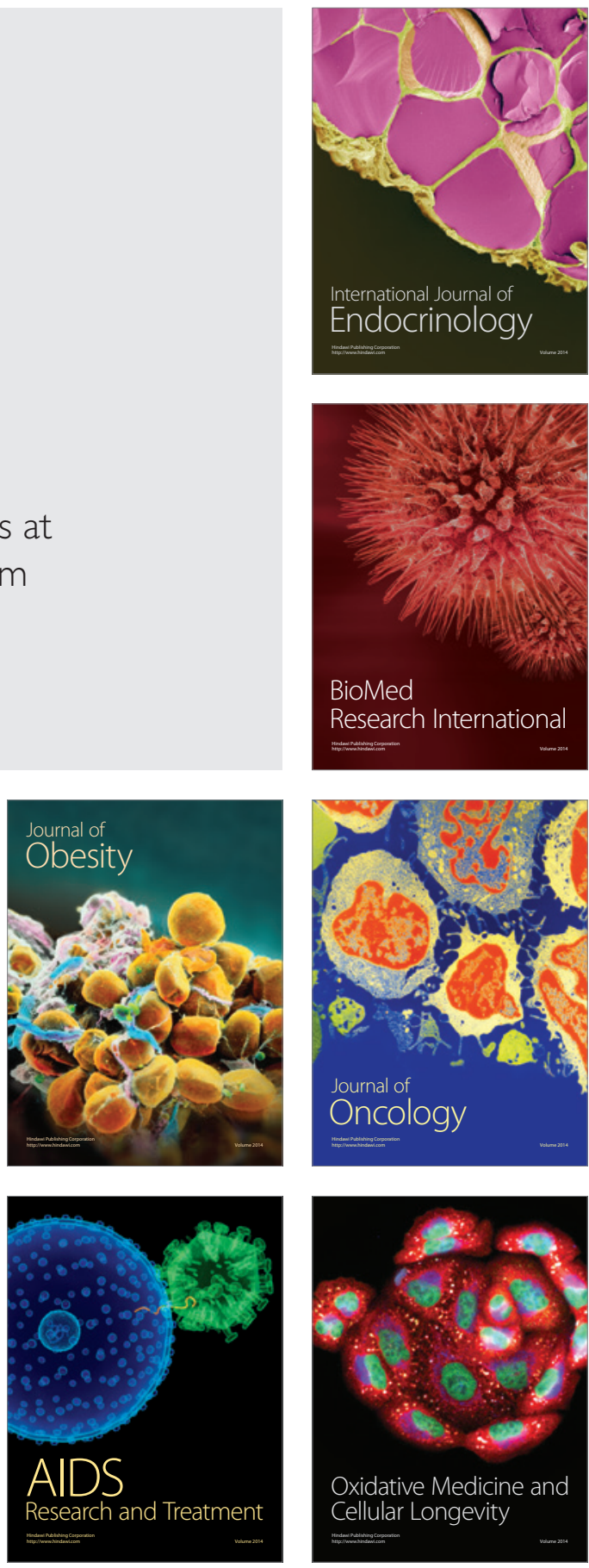